\title{
Control of Bacterial Wilt of Geranium with Phosphorous Acid
}

\author{
D. J. Norman, J. Chen, J. M. F. Yuen, A. Mangravita-Novo, D. Byrne, and L. Walsh, Department of Plant Pa- \\ thology, University of Florida, IFAS, Mid-Florida Research and Education Center, 2725 Binion Rd., Apopka 32703
}

\begin{abstract}
Norman, D. J., Chen, J., Yuen, J. M. F., Mangravita-Novo, A., Byrne, D., and Walsh, L. 2006. Control of bacterial wilt of geranium with phosphorous acid. Plant Dis. 90:798-802.

Various bactericides were screened for efficacy in protecting geranium plants (Pelargonium hortorum) from Ralstonia solanacearum infection. Many of these bactericides were found to slow the disease progress; however, they were not able to protect the plants from infection and subsequent death. Potassium salts of phosphorous acid were found to be effective in protecting plants from infection when applied as a drench. The active portion of the potassium salts was found to be phosphorous acid $\left(\mathrm{H}_{3} \mathrm{PO}_{3}\right)$. Phosphorous acid was found to inhibit in vitro growth of $R$. solanacearum. It is thought to be protecting plants from infection by acting as a bacteriostatic compound in the soil. The plants, however, are not protected from aboveground infection on wounded surfaces. Phosphorous acid drenches were shown to protect geranium plants from infection by either race 1 or 3 of $R$. solanacearum. Other phosphorous-containing products commonly used in the industry, such as phosphorus pentoxide $\left(\mathrm{P}_{2} \mathrm{O}_{5}\right)$ and phosphoric acid $\left(\mathrm{H}_{3} \mathrm{PO}_{4}\right)$, were not able to protect plants from bacterial wilt infection.
\end{abstract}

Additional keywords: ornamental foliage, southern bacterial wilt

Once it becomes established in a susceptible crop, southern bacterial wilt, caused by Ralstonia solanacearum (synonym Pseudomonas solanacearum), is very hard to eradicate. There are two primary avenues by which $R$. solanacearum moves and gains access to crops: one is via water, and the other is through infected propagation materials. In field crops, the spread by water can be rapid. The use of river water for irrigation has been linked to spread of the bacterial wilt pathogen $(3,26)$. In addition, alternate weed hosts can produce secondary inoculum, further facilitating spread and complicating disease management $(16,22,25)$. Infected propagation materials have been established as sources and means for movement of inoculum, especially in bananas (1), potatoes $(8,21)$, and ornamentals $(10,15,26)$.

To combat bacterial wilt, resistant cultivars have been recommended in areas of the world where the pathogen is endemic $(2,5,6,14)$. In susceptible greenhousegrown crops, only strict sanitation has been successful in prohibiting plant infestation. Sanitation measures usually include raised benches, cement floors, purified water, sterilization of tools, and the use of synthetic growing media (23). Even with these precautions, disease outbreaks can

Corresponding author: D. J. Norman

E-mail: djn@ifas.ufl.edu

Accepted for publication 3 February 2006

DOI: 10.1094/PD-90-0798

(C) 2006 The American Phytopathological Society occur, thought to be primarily due to workers disregarding sanitation guidelines necessary for the exclusion of $R$. solanacearum.

Geraniums (Pelargonium spp.) are susceptible to races 1 and 3 of $R$. solanacearum $(10,17,19,26)$. Most geraniums produced in the world are vegetatively propagated in Guatemala, Costa Rica, Columbia, China, and Kenya. In all these locations, endemic populations of $R$. solanacearum exist $(9,13,18,21)$. There are no known treatments that are effective in protecting geranium plants. Thus, the objective of this research was to determine if geranium plants could be protected from infection with applications of selected bactericides and chemicals.

\section{MATERIALS AND METHODS}

Screening of products. A race 1 (biovar 1) strain (R1B1) isolated in Florida (P673) from pothos (Epipremnum aureum (Linden $\&$ Andre) Blunt.) was used in the initial screening of prospective products. The isolates from pothos are of Central American origin and possess a broader host range than strains endemic in Florida (15). Using a race 1 strain meant a large number of products could be examined in a greenhouse situation without following USDA race 3 Select Agent regulations. Promising products were later tested in environmental chambers with a race 3 (biovar 2) strain (R3B2) isolated from geranium (UW551), provided by C. Allen, University of Wisconsin (20).

Initial active ingredients (products) tested included the following: aluminum tris (Aliette), benzothiadiazole (Actigard), copper sulfate (Cuprofix), copper hydroxide (Kocide 2000), copper pentahydrate (Phyton 27), copper salts (Camelot), hydrogen dioxide (Zerotol), furfuraldehyde (Multiguard), alkyl dimethyl benzyl ammonium chloride (Timsen), oxolinic acid (Starner), B. subtilis (Serenade, Companion), and potassium salts of phosphorous acid (K-Phite). The products were mixed in water at the highest labeled rates recommended by the manufacturers for plant production. Products are not labeled for control of Ralstonia. These products were applied as a drench through potting medium at $50 \mathrm{ml}$ per $9-\mathrm{cm}$ pot. In the initial screening, products were applied every 7 days for a total of four applications. Plants were inoculated with $R$. solanacearum 3 days after the first application. Products were not retested unless plants were protected from infection.

Products were screened with zonal geranium plants (Pelargonium hortorum) of either 'Americana Dark Red' or 'Patriot Red' provided by Goldsmith Seeds, Inc., Gilroy, CA, or Oglevee Ltd., Connellsville, PA, respectively. Rooted geranium cuttings were transplanted into 9-cm-diameter plastic pots containing $85 \mathrm{~g}$ of Vergo Container Mix A (60\% Canadian peat, $20 \%$ vermiculite, and $20 \%$ perlite by volume, $\mathrm{pH} 6.5$ ) and fertilized with $1.5 \mathrm{~g}$ of Osmocote 159-12 with micronutrients (The Scotts Co., Marysville, $\mathrm{OH}$ ) per pot. Plants were grown for a minimum of 4 weeks before treatments. Experiments were conducted in greenhouses with temperatures maintained between 18 and $32^{\circ} \mathrm{C}$ and light levels between 285 and $380 \mu \mathrm{mol} \cdot \mathrm{m}^{-2} \cdot \mathrm{s}^{-1}$. Plants were arranged in a completely randomized design with 10 plants per treatment. Colorcoded labels indicating treatment were used to remove subjectivity from wilt symptom evaluations. Two additional treatments were included in each test: a noninoculated control (saline, $8.5 \mathrm{~g}$ $\mathrm{NaCl} /$ liter applied without $R$. solanacearum) and a disease control (no product applied, inoculated with pathogen).

For inoculum production, $R$. solanacearum strains were grown on triphenyltetrazolium chloride (TZC) medium (11) for 48 $\mathrm{h}$, and cells were harvested and spectrophotometrically adjusted $\left(A_{600}\right)$ in saline to $5 \times 10^{8} \mathrm{CFU} / \mathrm{ml}$. Cell concentrations were confirmed by dilution plating onto TZC media. In the initial screening of products, $50 \mathrm{ml}$ of the cell suspension was drenched through potting medium of each geranium plant for a final concentration of $3 \times 10^{8}$ CFU/gram soil. 
Wilt symptoms were recorded as they occurred. Bacteria were reisolated 2 weeks after last treatment (6 weeks after inoculation) from plants without wilt symptoms. A cross-section of stem $1 \mathrm{~cm}$ in length was removed approximately 0.5 $\mathrm{cm}$ above the soil line of each geranium plant. Stem sections were dipped in a $10 \%$ bleach solution $(0.3 \% \mathrm{NaOCl})$, blotted, and ground in $300 \mu \mathrm{l}$ of sterile distilled water (SDW). Tissue suspensions were dilution streaked onto TZC medium and incubated for $48 \mathrm{~h}$ at $28^{\circ} \mathrm{C}$. Plates were examined for colonies having the typical mucoid red swirling egg-shaped pigmentation pattern of $R$. solanacearum described by Kelman (11).

Further testing of promising products. Geranium plants were found not to be systemically infected by $R$. solanacearum when treated with either K-Phite (a.i. $53 \%$ mono- and di-potassium salts of phosphorous acid) or Starner (a.i. 20\% oxolinic acid) at the initial test rates. To determine effective application rates and intervals for these products, four rates were tested (vol/vol, $0.25,0.5,0.75,1.0 \%)$ at three application regimes (one application; two applications at 14-day interval; and four applications at 7-day interval). Bactericides were applied 3 days before pathogen inoculation as in the initial product screen. Each treatment again contained 10 replicates. Using the R1B1 strain, four tests were conducted with two tests at each inoculum concentration: $5 \times 10^{8} \mathrm{CFU} / \mathrm{ml}$ $\left(3 \times 10^{8} \mathrm{CFU} / \mathrm{gram}\right.$ soil $)$, and $1 \times 10^{7}$ $\mathrm{CFU} / \mathrm{ml}\left(6 \times 10^{6} \mathrm{CFU} / \mathrm{gram}\right.$ soil $)$. Two additional controls (five plants each) were added at the lower inoculum rate to monitor concentrations of $R$. solanacearum within the potting medium. These controls consisted of: (i) pots containing potting medium without a geranium plant, yet inoculated with $R$. solanacearum, and (ii) pots containing potting medium without plant or $R$. solanacearum inoculation. Additional controls were watered like all other treatments. Six weeks after first chemical application, a cork borer (\#10, 15 $\mathrm{mm}$ diameter) was used to retrieve a $1-\mathrm{g}$ sample of potting medium from the first five replications of all treatments. A dilution series of the soil sample was done in SDW and replica-plated onto modified semiselective medium, South Africa (SMSA) agar (4). Typical $R$. solanacearum colonies were counted after $48 \mathrm{~h}$ growth at $28^{\circ} \mathrm{C}$. Bacteria were reisolated from all geranium plants 6 weeks after inoculation, as previously described. Colonies from plates with typical $R$. solanacearum growth pattern were suspended in saline $(8.5 \mathrm{~g} /$ liter $\mathrm{NaCl})$ and injected into parenchymatous tissue of tobacco (Nicotiana tabacum 'Hicks') for hypersensitive response (HR) following protocols of Lozano and Sequeira (12).

After the stem and soil reisolations, a seedling of tomato (Lycopersicon esculen- tum Mill. 'Walter') was transplanted into each pot of all treatments. This was done in order to determine if concentrations of $R$. solanacearum within the soil were sufficient for disease development. Tomato seedlings are very susceptible to both R1B1 and R3B2 Ralstonia strains. Tomatoes were monitored over a 4-week period (10 weeks from inoculation). If tomato plants wilted, reisolations were done as previously described along with the tobacco HR assay.

The R3B2 strain was tested in environmental chambers set on a 12-h day/night cycle $\left(19^{\circ} \mathrm{C}\right.$ night, $24^{\circ} \mathrm{C}$ day, $\left.310 \mu \mathrm{mol} \cdot \mathrm{m}^{-2} \cdot \mathrm{s}^{-1}\right)$. Two tests were conducted at an inoculum concentration of $5 \times$ $10^{8} \mathrm{CFU} / \mathrm{ml}\left(3 \times 10^{8} \mathrm{CFU} /\right.$ gram soil $)$. All other experimental parameters and controls were the same as previously described.

Antibacterial efficacy of compounds containing phosphorus (P). Many products containing $\mathrm{P}$ are currently sold in the ornamental plant industry as fertilizers or fungicides. Common ingredients include phosphorus pentoxide $\left(\mathrm{P}_{2} \mathrm{O}_{5}\right)$, phosphorous acid $\left(\mathrm{H}_{3} \mathrm{PO}_{3}\right)$, and phosphoric acid $\left(\mathrm{H}_{3} \mathrm{PO}_{4}\right)$ with mono- and/or di-potassium. We tested the efficacy for controlling bacterial wilt by $\mathrm{P}_{2} \mathrm{O}_{5}, \mathrm{H}_{3} \mathrm{PO}_{3}, \mathrm{H}_{3} \mathrm{PO}_{4}$, and $\mathrm{KCl}$. Reagent grade $\mathrm{KCl}$ and the three $\mathrm{P}$ chemicals buffered with $\mathrm{CaCO}_{3}$ were used in the first test, and the P chemicals only buffered with $\mathrm{KOH}$ were used in the second test. We used four concentrations of $\mathrm{P}$, $0.032,0.063,0.095$, and $0.127 \%$, for each of the three chemicals in the two tests; and the first four concentrations of $\mathrm{K}, 0.054$, $0.108,0.162$, and $0.216 \%$, were made from $\mathrm{KCl}$. As in the initial product, screening solutions were applied on a 7-day interval with four applications. Again, plants (10 per replication) were inoculated with strain P673 (R1B1) $\left(3 \times 10^{8} \mathrm{CFU} /\right.$ gram soil) 3 days after the first compound application. Two weeks after last application, all plants were sampled for $R$. solanacearum as previously described.

We measured the in vitro effect of phosphorous acid on the growth of both R1B1 (P673) and R3B2 (UW551) strains. Flasks containing $40 \mathrm{ml}$ of the following solutions were used: (i) $\mathrm{SDW}$, (ii) $\mathrm{SDW}+\mathrm{P}$ at $0.127 \%$ as $\mathrm{H}_{3} \mathrm{PO}_{3}$, (iii) $\mathrm{SDW}+\mathrm{K}$-Phite at $1 \%$, (iv) Nutrient broth (Difco) containing $5 \mathrm{~g}$ sucrose (NB), (v) NB + P at $0.127 \%$ as $\mathrm{H}_{3} \mathrm{PO}_{3}$, and (vi) $\mathrm{NB}+\mathrm{K}$-Phite at $1 \%$. The reagent grade $\mathrm{H}_{3} \mathrm{PO}_{3}$ treatments were buffered with $\mathrm{KOH}$ so that all treatments had a $\mathrm{pH}$ of 6.5. Twenty-four hour-old $R$. solanacearum culture from plates was suspended in three flasks of each treatment to a concentration of $5 \times 10^{6} \mathrm{CFU} / \mathrm{ml}$. Flasks were placed on an orbital shaker at 120 $\mathrm{rpm}$ at a temperature of $28^{\circ} \mathrm{C}$. Concentrations of viable cells in each flask were enumerated on $0,1,7,14,21$, and 28 days. Cell were counted by plating $100 \mu \mathrm{l}$ of a 10 -fold dilution series onto TZC medium and incubating for $48 \mathrm{~h}$ at $28^{\circ} \mathrm{C}$. Counts were discontinued when concentrations of cells reached $10^{9} \mathrm{CFU} / \mathrm{ml}$.

Safety of K-Phite to crop. To determine if phytotoxicity occurred with the KPhite product, an experiment was set up as previously described using four concentrations (vol/vol, $0.50,0.75,1$, and $2 \%$ ) with 10 plants per treatment. The experiment was repeated twice. The compounds were applied five times on a 7-day interval without pathogen inoculation. Dry weights of both roots and foliage of all plants were determined at the end of the test. In addition, we measured medium $\mathrm{pH}$ and soluble salts for five plants of each treatment and performed a complete foliar analysis (Fafard, Inc., Agawam, MA).

\section{RESULTS}

Screening of products. In the initial testing, nearly all the products slowed disease progress. However, they did not protect the plants from infection, except for benzothiadiazole (Actigard), oxolinic acid (Starner), and potassium salts of phosphorous acid (K-Phite) (data not shown). Further testing of benzothiadiazole was discontinued due to leaf abscission. This abscission occurred even at rates as low as $5 \mu \mathrm{l} /$ liter. In the initial tests, none of the geranium plants treated with $1 \%$ (vol/vol, 7-day interval) of either of Starner or K-Phite had any wilt symptoms. Nor could $R$. solanacearum be isolated from geranium stems. Therefore, we continued testing these two products.

Further testing of promising products. Low rates and intervals of Starner were ineffective in protecting plants from infection. High rates above $0.5 \%$ (vol/vol) on a 7-day interval provided protection for the majority of the plants. However, at inoculation rates: of $3 \times 10^{8} \mathrm{CFU} / \mathrm{gram}$ soil and $6 \times 10^{6} \mathrm{CFU} /$ gram soil, systemic infections were occasionally observed in plants treated with 0.75 and $1 \%$ Starner. Due to the high rates and intervals required for disease protection, testing of Starner was discontinued.

K-Phite was fairly effective in protecting geranium plants from infection at $3 \times 10^{8}$ CFU/gram soil (Fig. 1) and very effective in protecting plants at $6 \times 10^{6} \mathrm{CFU} /$ gram soil. At the lower inoculation rate, $95 \%$ of the geranium plants inoculated with P673 (R1B1) were protected from infection with a one-time application of a $1 \%(\mathrm{vol} / \mathrm{vol})$ solution of K-Phite. The R3B2 strain (UW551) was far less aggressive on geranium than the R1B1 strain (P673). At high levels of inoculum $\left(3 \times 10^{8} \mathrm{CFU} /\right.$ gram soil), K-Phite was effective in protecting plants from infection of R3B2 at 0.75 to $1 \%$ with one application (Fig. 1).

Populations of $R$. solanacearum were not detectable in the soil after potting medium was drenched with K-Phite for either two or four applications (Fig. 2). In addition, large variations existed in populations found in the soil matrix within treatments. 


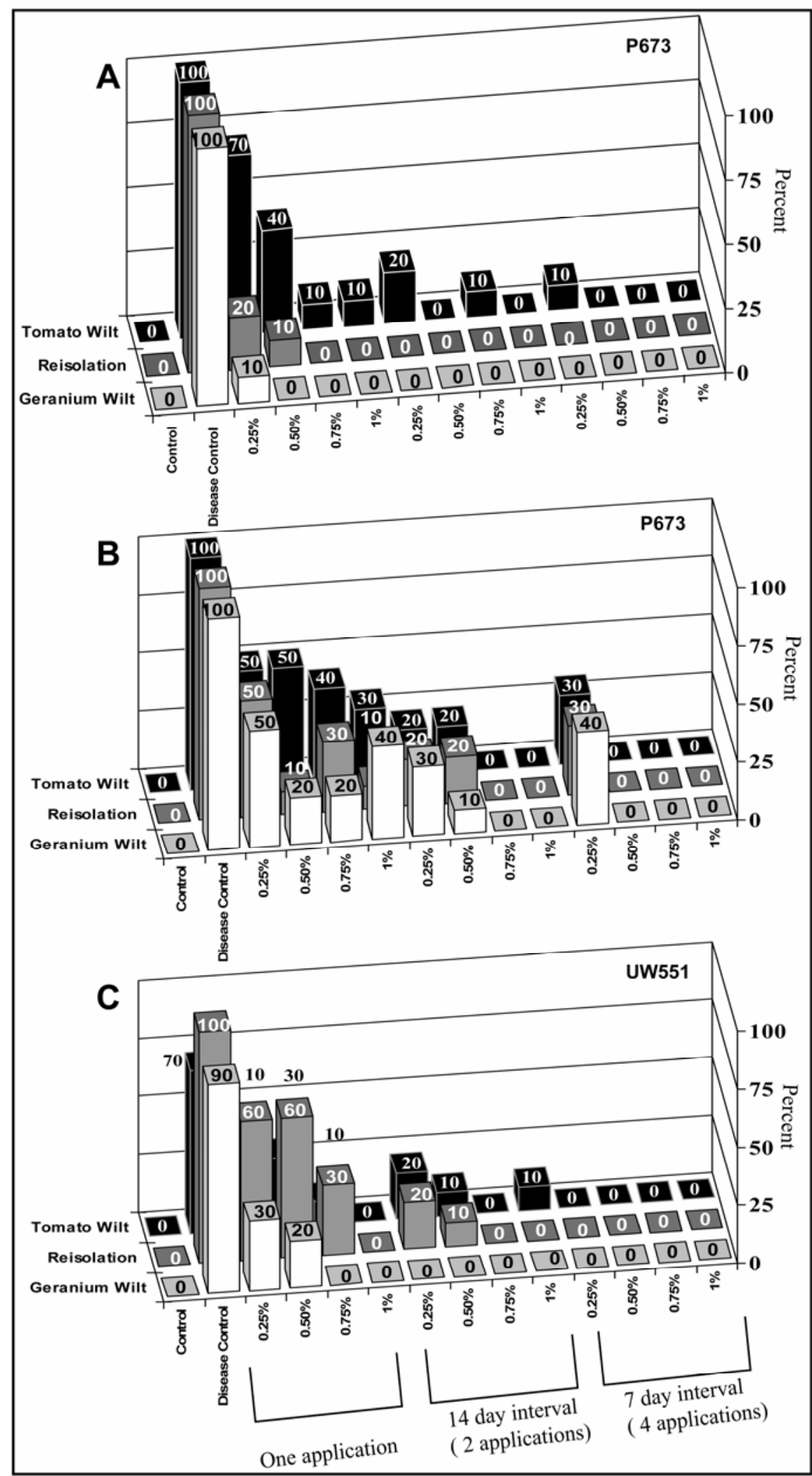

Fig. 1. Effects of K-Phite application on control of Ralstonia solanacearum infection. K-Phite was diluted as indicated and applied at $50 \mathrm{ml}$ per $9-\mathrm{cm}$ pot either once, twice at a 14-day interval, or four times at a 7-day interval. First row of each bar graph represents the percentage of geranium plants expressing wilt symptoms 6 weeks after inoculation. Second row represents the number of plants found to be systemically infected 6 weeks after inoculation. Third row represents the number of tomato plants with symptoms 10 weeks after soil inoculation with $R$. solanacearum. A, medium inoculated with R1B1 strain (P673) at $6 \times 10^{6} \mathrm{CFU} /$ gram soil; B, medium inoculated with R1B1 strain (P673) at $3 \times 10^{8} \mathrm{CFU} /$ gram soil; and C, R3B2 strain (UW551) inoculated at $3 \times 10^{8} \mathrm{CFU} / \mathrm{gram}$ soil (10 plants per treatment).
Systemically infected plants had high soil populations, frequently greater than $10^{6}$ CFU/gram soil, while noninfected plants had low to undetectable populations within the soil matrix. Again, the R1B1 strain was more persistent than the R3B2 strain, with high populations present in the untreated soil control not containing a geranium plant 6 weeks after inoculation (Fig. 2), while the R3B2 strain was undetectable at that time.

Efficacy of phosphorous compounds. K-Phite effectively protected geranium plants from infection with the R1B1 strain at all four applied rates (Fig. 3). Since it is a product of potassium salts of phosphorous acid, three $\mathrm{P}$ chemicals, $\mathrm{P}_{2} \mathrm{O}_{5}, \mathrm{H}_{3} \mathrm{PO}_{3}$, and $\mathrm{H}_{3} \mathrm{PO}_{4}$, were tested. Due to the unknown of the exact $\mathrm{P}$ concentration in the K-Phite, four $\mathrm{P}$ concentrations (0.032, $0.063,0.095$, and $0.127 \%$ ) for the three chemicals were chosen. Phosphorous acid $\left(\mathrm{H}_{3} \mathrm{PO}_{3}\right)$ protected plants at the four applied concentrations similarly to K-Phite; whereas phosphorus pentoxide $\left(\mathrm{P}_{2} \mathrm{O}_{5}\right)$ provided no protection, phosphoric acid $\left(\mathrm{H}_{3} \mathrm{PO}_{4}\right)$ gave only slight protection, and potassium $(\mathrm{KCl})$ none. Results were similar for tests done with both $\mathrm{CaCO}_{3}$ and $\mathrm{KOH}$ as buffering systems.

The long-term in vitro growth curves were similar for both bacterial strains tested. In Figure 4, results are displayed for UW551. Phosphorous acid either in reagent grade or product form inhibited cell replication in NB and SDW (Fig. 4). The inhibitory effect of phosphorous acid on growth lasted approximately 14 days. Culturable cell counts stabilized within the SDW treatments, and growth began to occur in NB treatments containing phosphorous after 14 days.

Safety of K-Phite to crop. There was a significant $(P=0.5)$ increase in the geranium shoot dry weight of $27 \%$ with the $1 \%$ K-Phite treatment relative to the water control. All other shoot dry weights were not significantly different from the water control. There was an observed $17 \%$ decrease in shoot dry weight with the $2 \% \mathrm{~K}$ Phite treatment, although it was not significantly different. A significant decrease $(P=0.5)$ in root mass was observed at all application levels with an $R^{2}$ value of 0.96 . Compared with the water control, there was a 22 and $47 \%$ decrease in root mass at the 1 and $2 \%$ application rates. There were no significant differences in potting medium $\mathrm{pH}$ or soluble salts among geranium plants treated with different rates of KPhite. Applications of K-Phite notably raised the concentration of phosphorous $\left(R^{2}=0.71\right)$ within the foliage from 0.43 ppm (water control) to $1.21 \mathrm{ppm}(2 \%$ level). Potassium levels also increased $\left(R^{2}\right.$ $=0.98$ ) from $4.3 \mathrm{ppm}$ (water control) to $6.32 \mathrm{ppm}$ ( $2 \%$ level). Iron levels decreased from $122.5 \mathrm{ppm}$ to $45.7 \mathrm{ppm}\left(R^{2} 0.58\right)$. Leaves were less green on plants treated with $1 \% \mathrm{~K}$-Phite than on plants treated 
with water. Interveinal leaf chlorosis occurred in plants treated with $2 \%$ K-Phite. The interveinal chlorosis was minimized by applying K-Phite at much lower rates $(\leq 1 \%)$ and application intervals (14-day rather than 7-day) while still protecting geranium from infection. We also found that leaf chlorosis could be prevented with additional foliar applications of chelated iron (data not shown). In order to maintain healthy geranium plants, the K-Phite product should not be drenched at rates above $1 \%$ on a prolonged basis.

\section{DISCUSSION}

The majority of the geraniums sold in the global north are produced in countries where labor costs and environmental conditions make asexual propagation economically feasible, but where $R$. solanacearum is endemic. In order to exclude $\mathrm{R} 3 \mathrm{~B} 2$ from these geranium production facilities, rigorous sanitation measures are being implemented (24). However, complete eradication of bacterial wilt is difficult given an environment conducive to both host and pathogen. Thus, in addition to sanitation and resistant cultivars, growers need other control options.

This study showed that most of the tested products slowed the progression of bacterial wilt on geranium, but did not protect the plants from infection and subsequent death. Only phosphorous acid protected plants from infection. Phosphorus compounds have been reported to control some fungal pathogens, and mechanisms underlying the disease control have been hypothesized to be either direct antifungal activity or stimulated host defense responses from infected plants (7). This study demonstrated that phosphorous acid protected geranium plants from infection by a bacterial pathogen, $R$. solanacearum. It appears that the protection occurs in the soil and root matrix, as pathogen cells could not be cultured from the potting medium of treatments with high frequency and application rates of K-Phite (Fig. 2).

The mechanism by which phosphorous acid inhibits growth of $R$. solanacearum is not known. Only phosphorous acid $\left(\mathrm{H}_{3} \mathrm{PO}_{3}\right)$, not phosphorus pentoxide $\left(\mathrm{P}_{2} \mathrm{O}_{5}\right)$ or phosphoric acid $\left(\mathrm{H}_{3} \mathrm{PO}_{4}\right)$, was effective in control of this pathogen (Figs. 2 and 3). One difference among the three compounds is that $\mathrm{P}$ in $\mathrm{P}_{2} \mathrm{O}_{5}$ and $\mathrm{H}_{3} \mathrm{PO}_{4}$ has valence 5 but the valence is 3 in $\mathrm{H}_{3} \mathrm{PO}_{3}$. Whether the valence differences made the difference in this pathogen control is unknown. Nevertheless, this study showed that pathogen growth appeared to be halted and bacterial ability to naturally infect roots was limited. When $R$. solanacearum cells were placed into SDW containing $\mathrm{H}_{3} \mathrm{PO}_{3}$, the number of culturable cells gradually decreased over time (Fig. 4). There is a possibility that these cells are in a Viable-But-Nonculturable State (VBNC). VBNC is known to occur with $R$. solanacearum under certain conditions (24). How-

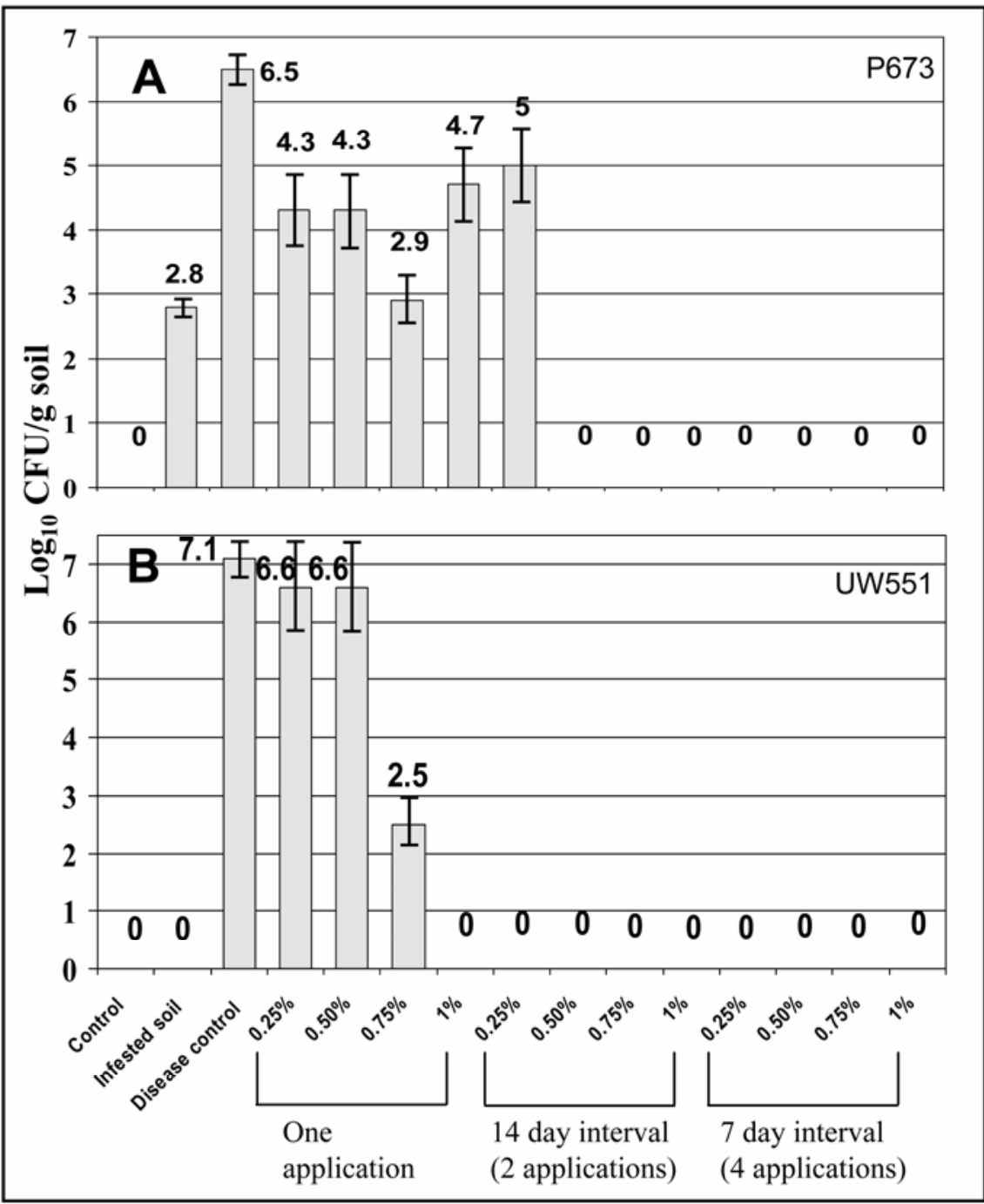

Fig. 2. Mean concentrations of Ralstonia solanacearum cells in potting medium 6 weeks after application of K-Phite. A, medium inoculated with R1B1 strain (P673) at $6 \times 10^{6} \mathrm{CFU} / \mathrm{gram}$ soil. B, medium inoculated with R3B2 strain (UW551) at $3 \times 10^{8} \mathrm{CFU} /$ gram soil (10 plants per treatment).

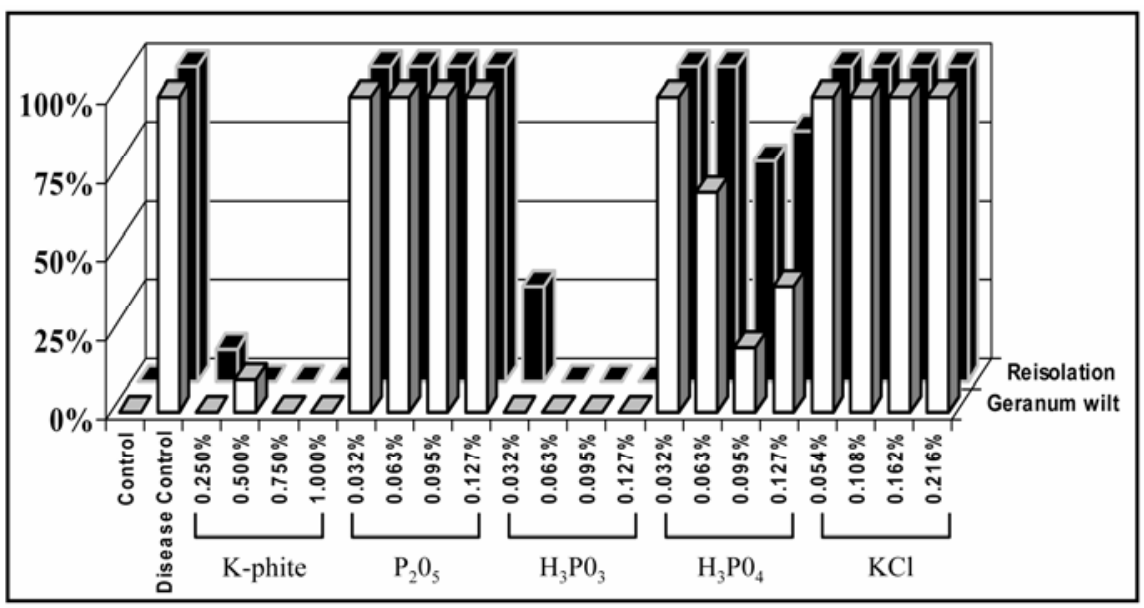

Fig. 3. Relative effects of K-Phite and phosphorus compounds in control of Ralstonia solanacearum (strain P673, R1B1). K-Phite was diluted as indicated, whereas concentrations of phosphorus (P) compounds and $\mathrm{KCl}$ are based on the percentage of $\mathrm{P}$ or $\mathrm{K}$. K-Phite, $\mathrm{P}$ and $\mathrm{K}$ solutions were applied at 50 $\mathrm{ml}$ per $9-\mathrm{cm}$ pot. First row of bars represents the percentage of geranium plants with wilt symptoms, and second row of bars represents those that were found to be systemically infected 6 weeks after inoculation. Each treatment was applied four times at 7 -day intervals (10 plants per treatment). Results were similar when test was repeated. 


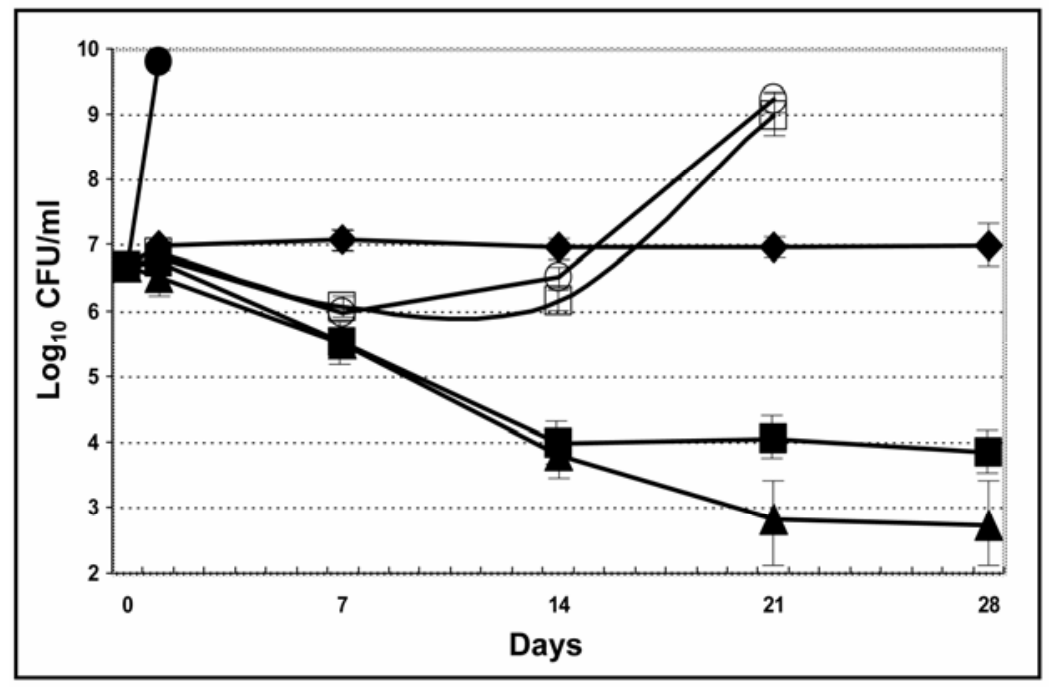

Fig. 4. Growth of Ralstonia solanacearum UW551 in flasks containing $40 \mathrm{ml}$ of the following solu-

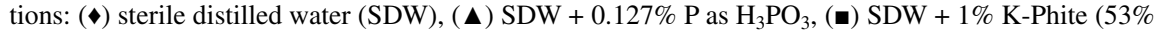
mono- and di-potassium salts of phosphorous acid), $(\bullet)$ Nutrient broth Difco containing $5 \mathrm{~g}$ sucrose (NB), (口) $\mathrm{NB}+0.127 \% \mathrm{P}_{\text {as }} \mathrm{H}_{3} \mathrm{PO}_{3}$, and (०) $\mathrm{NB}+1 \%$ K-Phite.

ever, regardless of the state of the cells, their ability to infect plants appears to be compromised by phosphorous acid treatment. Van Overbeek et al. (24) has shown that VBNC cells eventually lose their capacity to cause disease.

The periodic use of phosphorous acidcontaining products would be an effective safeguard against southern bacterial wilt developing following inadvertent introduction of R3B2 into production facilities. It would also be an effective method of combating race 1 outbreaks that can also occur in production facilities both in and out of the United States. The R1B1 isolate appeared in this study to be far more aggressive and harder to control on geranium than the R3B2 isolate. In addition, the R1B1 isolate survived better than the $\mathrm{R} 3 \mathrm{~B} 2$ isolate in planting media without the presence of a plant (Fig. 2). Broad conclusions regarding pathogenicity and survival of these two races of $R$. solanacearum should not be made from these results. The difference observed in pathogenicity and survival between these two strains may be strain specific or related to environmental differences between tests conducted in greenhouse and environmental chambers.

Phosphorous acid applications are not curative. Once plants were systemically infected, wilt and death eventually occurred. Phosphorous acid does not prevent plant wilt and death when geranium stems are inoculated with low concentrations of $R$. solanacearum (data not shown). Thus, phosphorous acid applications would not contribute to the formation of asymptomatic plants. Applications would only protect plants that are not yet infected. However, the effectiveness and safety of the various products sold containing phosphorous acid would depend on the concentration of $\mathrm{H}_{3} \mathrm{PO}_{3}$, inert ingredients, and buffering system.

\section{ACKNOWLEDGMENTS}

This research was funded by a USDA Floral Industry Task Force Specific Cooperative Agreement, IR4, and the University of Florida Institute of Food and Agricultural Sciences.

\section{LITERATURE CITED}

1. Buddenhagen, I. W. 1961. Bacterial wilt of bananas: History and known distribution. Trop. Agric. (Trinidad) 38:107-121

2. Collonnier, C., Mulya, K., Fock, I., Mariska, I., Servaes, A., Purwito, A., Vedel, F., SiljakYakovlev, S., Souvannavong, V., Ducreux, G., and Sihachakr, D. 2001. Sources of resistance against Ralstonia solanacearum in fertile somatic hybrids of eggplant (Solanum melongena L.) and Solanum aethiopicum L. Plant Sci. 160:301-313.

3. Elphinstone, J. G. 1996. Survival and possibilities for extinction of Pseudomonas solanacearum (Smith) Smith in cool climates. Potato Res. 39:403-410.

4. Elphinstone, J. G., Hennessey, J., Wilson, J. K., and Stead, D. E. 1996. Sensitivity of different methods for the detection of Ralstonia solanacearum in potato tuber extracts. EPPO Bull. 26:663-678.

5. Fock, I., Collonnier, C., Luisetti, J., Purwito, A., Souvannavong, V., Vedel, F., Servaes, A., Ambroise, A., Kodja, H., Ducreux, G., and Sihachakr, D. 2001. Use of Solanum stenotomum for introduction of resistance to bacterial wilt in somatic hybrids of potato. Plant Physiol. Biochem. 39:899-908.

6. Fock, I., Collonnier, C., Purwito, A., Luisetti, J., Souvannavong, V., Vedel, F., Servaes, A., Ambroise, A., Kodja, H., Ducreux, G., and Sihachakr, D. 2000. Resistance to bacterial wilt in somatic hybrids between Solanum tuberosum and Solanum phureja. Plant Sci. 160:165176.

7. Guest, D., and Grant, B. 1991. The complex action of phosphonates as antifungal agents.

8. Harrison, D. E. 1961. Bacterial wilt of potatoes, field symptoms of the disease and studies on the causal organism, Pseudomonas solanacearum variety asiaticum. Aust. J. Agric. Res. 12:854-871.

9. He, L. Y., Sequeira, L., and Kelman, A. 1983. Characteristics of strains of Pseudomonas solanacearum from China. Plant Dis. 67:13571361.

10. Janse, J. D., Beld, H. E. V. D., Elphinstone, J., Biol. Rev. 66:159-187.
Simpkins, S., Tjou-Tam-Sin, L. N. A., and Vaerenbergh, J. V. 2005. Introduction to Europe of Ralstonia solanacearum biovar 2, race 3 in Pelargonium zonale cuttings. In Bacterial Wilt: The Disease and the Ralstonia solanacearum Species Complex. C. Allen, P. Prior, and A. C. Hayward, eds. American Phytopathological Society, St. Paul, MN.

11. Kelman, A. 1954. The relationship of pathogenicity in Pseudomonas solanacearum to colony appearance on tetrazolium medium. Phytopathology 44:693-695.

12. Lozano, J. C., and Sequeira, L. 1970. Differentiation of races of Pseudomonas solanacearum by leaf infiltration technique. Phytopathology 60:833-838.

13. Martin, C., French, E. R., and Nydegger, U. 1982. Strains of Pseudomonas solanacearum affecting solanaceae in the Americas. Plant Dis. 66:458-460.

14. Mohamed, M. E. S., Umaharan, P., and Phelps, R. H. 1997. Genetic nature of bacterial wilt resistance in tomato (Lycopersicon esculentum Mill.) accession LA 1421. Euphytica 96:323326.

15. Norman, D. J., and Yuen, J. M. F. 1998. A distinct pathotype of Ralstonia (Pseudomonas) solanacearum race 1, biovar 1 entering Florida on infected pothos (Epipremnum aureum) cuttings. Can. J. Plant Pathol. 20:171-175.

16. Pradhanang, P. M., Elphinstone, J. G., and Fox, R. T. V. 2000. Identification of crop and weed hosts of Ralstonia solanacearum. Plant Pathol. 49:403-413.

17. Pradhanang, P. M., Momol, M. T., Dankers, H., and Jones, J. B. 2002. First report of Southern wilt caused by Ralstonia solanacearum in geranium in Florida. Plant Health Progress, June 11, 2002:1-2. Online publication.

18. Smith, J. J., Offord, L. C., Holderness, M., and Saddler, G. S. 1995. Genetic diversity of Burkholderia solanacearum (synonym Pseudomonas solanacearum) race 3 in Kenya. Appl. Environ. Microbiol. 61:4263-4268.

19. Strider, D. L., Jones, R. K., and Haygood, R. A. 1981. Southern bacterial wilt of geranium caused by Pseudomonas solanacearum. Plant Dis. 65:52-53.

20. Swanson, J. K., Yao, J., Tans-Kersten, J., and Allen, C. 2005. Behavior of Ralstonia solanacearum race 3 biovar 2 during latent and active infection of geranium. Phytopathology 95:136143.

21. Thurston, H. D. 1963. Bacterial wilt of potatoes in Colombia. Am. Potato J. 40:381-390.

22. Tusiime, G., Adipala, E., Opio, F., and Bhagsari, A. S. 1998. Weeds as latent hosts of Ralstonia solanacearum in highland Uganda: Implications to development of an integrated control package for bacterial wilt: In Bacterial Wilt Disease: Molecular and Ecological Aspect. P. Prior, C. Allen, and J. Elphinstone, eds. Springer Verlag, Berlin.

23. U.S. Dep. Agric. APHIS. 2004. Minimum sanitation protocols for offshore geranium cutting production. USDA-APHIS.

24. van Overbeek, L. S., Bergervoet, J. H. W., Jacobs, F. H. H., and van Elsas, J. D. 2004 The low-temperature-induced viable-butnonculturable state affects the virulence of Ralstonia solanacearum biovar 2. Phytopathology 94:463-469.

25. Wenneker, M., Verdel, M. S. W., Groeneveld, R. M. W., Kempenaar, C., Beuningen, A. R. V., and Janse, J. B. 1999. Ralstonia (Pseudomonas) solanacearum race 3 (biovar 2) in surface water and natural weed hosts: First report on stinging nettle (Urtica dioica). Eur. J. Plant Pathol. 105:307-315.

26. Williamson, L., Nakaho, K., Hudelson, B., and Allen, C. 2002. Ralstonia solanacearum race 3 biovar 2 strains isolated from geranium are pathogenic on potato. Plant Dis. 86:987-991. 


\section{ERRATUM}

A change was made to this article on May 25, 2006. In the abstract, the sentence that starts on line 9 was corrected to read: Phosphorous acid drenches were shown to protect geranium plants from infection by either race 1 or 3 of $R$. solanacearum. 